\title{
Two early rehabilitation training models in male patients after coronary artery bypass surgery: application of continuous walking training as an alternative to interval cycle ergometer training
}

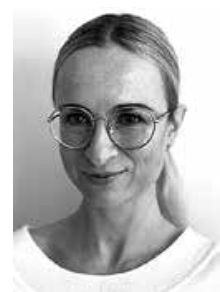

\author{
Dorota Dolecińska, Izabela Przywarska¹, Tomasz Podgórski², Piotr Dylewicz ${ }^{1}$ \\ ${ }^{1}$ Department of Cardiological and Rheumatological Rehabilitation, Poznan University of Physical Education, Poznan, Poland \\ 2Department of Physiology and Biochemistry, Poznan University of Physical Education, Poznan, Poland
}

Kardiochir Torakochir Pol 2020, 17 (2): 87-93

\begin{abstract}
Introduction: Walking training is a good alternative to the commonly used cycle ergometer training. It is still necessary to develop rehabilitation programs based on walking characterized by a high degree of safety and effectiveness.

Aim: Application of continuous walking training as an alternative to interval cycle ergometer training in men after coronary artery bypass graft (CABG) surgery, using the 6-minute walk test (6-MWT) to determine the initial training load.

Material and methods: Forty-four men aged 45 to 76 years, up to 3 months after CABG surgery, were randomly assigned to continuous training on a treadmill (study group) or interval training on a cycle ergometer (control group), performed 6 times per week (12-15 sessions). Participants underwent the treadmill exercise stress test (TEST) and 6-MWT at the begining and after completion of the rehabilitation program. Before and 3 minutes after the $6^{\text {th }}$ and $12^{\text {th }}$ training session blood lactate concentration was determined.

Results: Energy expenditure in TEST increased from 4.4 to 6.3 MET in the study group and from 5.0 to 6.5 MET in the control group. Distance walked in 6-MWT increased from 420 to 519 $\mathrm{m}$ and from 438 to $510 \mathrm{~m}$, respectively. Resting heart rate (HR) and double product (DP) decreased only in the study group as well as systolic blood pressure (SBP), HR and DP at peak exercise load in baseline TEST. Mean energy expenditure during training sessions was 2.6 MET in the study group and 2.8 MET in the control group (NS). Exercise blood lactate concentration did not exceed $2.0 \mathrm{mmol} / \mathrm{l}$ in both groups.

Conclusions: Both rehabilitation programs were of similar effectiveness and their intensity did not exceed the anaerobic threshold.
\end{abstract}

Key words: blood lactate concentration, cardiac rehabilitation, coronary artery bypass grafting, cycle ergometer training, walking training.

\section{Streszczenie}

Wprowadzenie: Marsz stanowi alternatywę dla powszechnie wykorzystywanych treningów cykloergometrycznych. Dlatego potrzebne jest opracowywanie programów rehabilitacyjnych opartych na marszu, charakteryzujących się wysokim stopniem bezpieczeństwa i skuteczności.

Cel pracy: Wykorzystanie testu 6-minutowego marszu (6-MWT) do wyznaczania obciążenia początkowego u mężczyzn po operacji pomostowania aortalno-wieńcowego (CABG).

Materiał i metody: Czterdziestu czterech mężczyzn w wieku od 45 do 76 lat, do 3 miesięcy po operacji CABG przydzielono losowo do ciągłego treningu na bieżni (grupa badana) lub interwałowego treningu na cykloergometrze (grupa kontrolna), wykonywanych 6 razy w tygodniu (12-15 sesji). Uczestnicy zostali poddani testowi wysiłkowemu na bieżni (TEST) oraz 6-MWT przed rozpoczęciem programu rehabilitacji i po zakończeniu. Przed ukończeniem i 3 minuty po ukończeniu 6. i 12. sesji treningowej oznaczono stężenie mleczanu we krwi.

Wyniki: Wydatek energetyczny w TEST wzrósł z 4,4 do 6,3 MET w grupie badanej i z 5,0 do 6,5 MET w grupie kontrolnej. Dystans pokonany w 6-MWT wydłużył się odpowiednio z 420 do 519 m i z 438 do 510 m. Spoczynkowe tętno (HR) i podwójny iloczyn (DP) zmniejszyły się tylko w grupie badanej, podobnie jak ciśnienie skurczowe (SBP), HR i DP na poziomie szczytowego obciążenia we wstępnym TEST. Średni wydatek energetyczny podczas treningów wyniósł 2,6 MET w grupie badanej i 2,8 MET w grupie kontrolnej (NS). Stężenie mleczanu we krwi nie przekraczało poziomu 2,0 $\mathrm{mmol} / / \mathrm{w}$ obu grupach.

Wnioski: Oba programy rehabilitacyjne charakteryzowała podobna efektywność, a ich intensywność nie prowadziła do przekroczenia progu beztlenowego.

Słowa kluczowe: stężenie mleczanu we krwi, rehabilitacja kardiologiczna, pomostowanie aortalno-wieńcowe, trening cykloergometryczny, trening marszowy. 
Two early rehabilitation training models in male patients after coronary artery bypass surgery: application of continuous walking training as an alternative to interval cycle ergometer training

\section{Introduction}

Atherosclerotic changes in coronary arteries contribute to development of cardiovascular diseases, being the leading cause of death. Coronary artery bypass grafting (CABG) surgery improves myocardial blood supply and remains one of the most frequently performed surgical procedures [1].

Continuous or interval training using a cycle ergometer or treadmill is a recommended form of rehabilitation after CABG surgery, but its intensity should not exceed the anaerobic threshold [2], where blood lactate concentration (BLC) reaches $4 \mathrm{mmol} / \mathrm{l}$ [3]. Rehabilitation programs based on walking are an excellent alternative to the commonly used cycle ergometer training, hence there is a need for developing new ones [4].

\section{Aim}

The aim of this study was to apply continuous walking training as an alternative to interval cycle ergometer training in men after CABG surgery, using the 6-minute walk test (6-MWT) to determine the initial training load.

\section{Material and methods \\ Study participants}

We recruited 44 consecutive patients aged 45 to 76 years after CABG surgery, who were admitted to the Cardiac Rehabilitation Ward of the Provincial Hospital in Poznan, Poland. This study was conducted in accordance with the amended Declaration of Helsinki. Poznan University of Medical Sciences Bioethics Committee approved the protocol (841/13) and written informed consent was obtained from all patients.

Inclusion criteria were male gender, CABG surgery performed in the last 3 months, completion of at least 12, but no more than 15, training sessions and participation in preliminary and final tests. Exclusion criteria were contraindications to the treadmill exercise stress test (TEST) [5]. In order of admission to the ward patients were alternately assigned to continuous training on a treadmill (study group) or standard interval training on a cycle ergometer (control group).

\section{Study design}

Participants underwent a clinical assessment including TEST and 6-MWT at the begining and after completion of the rehabilitation program. All patients participated in one training session a day and 20 minutes exercises in a sitting position on a chair performed twice a day, 6 times per week.

The exercise stress test was carried out on a Full Vision Inc. treadmill (TMX425, USA), using the Welch Allyn CardioPerfect (USA) workstation and a 3-minute incremental protocol (Modified Bruce 2). The 12-lead ECG and blood pressure (BP) were continuously obtained. The end point was assessed according to criteria of the American Heart Association [5] or reaching 15 points in the 20-grade Borg Scale. During the recovery phase, participants were advised to continue walking with a speed of $2.0 \mathrm{~km} / \mathrm{h}$ and a slope of $0 \%$ for 1 minute, while in the $3^{\text {rd }}$ and $4^{\text {th }}$ minute patients were sitting. Oxygen uptake $\left(\mathrm{VO}_{2}\right)$ was estimated using METs [6], and maximum heart rate $\left(\mathrm{HR}_{\max }\right)$ was calculated based on the equation $H R_{\text {max }}=220$ - age.

The 6-MWT was conducted in accordance with the American Thoracic Society guidelines [7], on a $25 \mathrm{~m}$ long corridor. HR and BP were measured before and after the test. Predicted walking distance $[8,9]$ and $\mathrm{VO}_{2}[10]$ were estimated using an equation. Energy expenditure (MET) was determined by dividing the $\mathrm{VO}_{2}$ value by 3.5 [6]. The 20-grade Borg Scale for rating perceived exertion was used.

The basis for determining the individual initial training load for patients from the study group was the result of the 6-MWT. Predicted peak $\mathrm{VO}_{2}$ was calculated using the equation [10]:

Peak $\mathrm{VO}_{2}=0.02 \times$ distance $(\mathrm{m})-0.191 \times$ age (years) $0.07 \times$ weight $(\mathrm{kg})+0.09 \times$ height $(\mathrm{cm})+0.26 \times \mathrm{DP} \times 0.001$ +2.45 .

Distances at $50 \%, 60 \%$ and $70 \%$ of peak $\mathrm{VO}_{2}$ were estimated, assuming respectively $50 \%, 60 \%$ and $70 \%$ of baseline peak $\mathrm{VO}_{2}$ and double product (DP) values. Age, body weight and height were constant. Values of predicted distances at $50 \%, 60 \%$ and $70 \%$ of peak $\mathrm{VO}_{2}$ allowed initial speeds of walking to be determined by dividing distance values by 100 . Depending on general condition - the patient started walking on a flat treadmill (Kettler Track Experience, Germany) with estimated speed of $50 \%, 60 \%$ or $70 \%$ of peak $\mathrm{VO}_{2}$.

The first session lasted 10 minutes, and the next ones were gradually extended to 20 minutes. Walking speed was increased individually depending on the patient's general condition every $2-5$ sessions by $0.2-0.5 \mathrm{~km} / \mathrm{h}$. Maximum speed was limited by the value at which the participant made a switch from walking to running.

The basis for determining the individual initial training load for patients from the control group was a result of TEST. Depending on general condition, the patient was given a maximum initial load of $50 \%$ to $70 \%$ of METs that were converted into watts [11].

A single training session lasted approximately 20 minutes and consisted of 6 to 11 intervals of increasing the load to half of training duration and decreasing until its completion. Load intervals lasted $0.5-1$ minutes and were separated by 1 minute active recovery (no load pedaling). Each session started and ended with 1 minute active recovery. Subjects were asked to maintain cycling speed of 60-70 rpm.

The ECG, HR and BP were obtained during all sessions. The 20-grade Borg Scale for rating perceived exertion was used. Energy expenditure in METs [6] and caloric expenditure [11] were estimated individually for each walking training session and cycle ergometer training session [12].

Capillary blood arterialized by rubbing the fingertip was collected around the $6^{\text {th }}$ and $12^{\text {th }}$ sessions, before and 3 minutes after training. BLC was determined using the enzymatic spectrophotometric method [13]. Absorbance values were read on the Synergy 2 SIAFRT Multi-Mode Microplate Reader (BioTek Instruments, USA) at a wavelength of $340 \mathrm{~nm}$. 


\section{Statistical analysis}

The Shapiro-Wilk test was used to check normality of distribution. Student's $t$-test, the Mann-Whitney test, the Wilcoxon signed rank test, the $\chi^{2}$ test or Fisher's exact test was used to compare variables. Friedman's ANOVA and a post-hoc test were used to analyze repeated measures. Values of $p<0.05$ were considered statistically significant. Statistica version 13.1 software (Dell Inc., USA) was used for statistical analysis.

\section{Results}

\section{Participant characteristics}

Forty-one patients completed rehabilitation programs. Three patients were excluded from the study due to: (1) complaints related to abdominal aortic and iliac aneurysms, (2) bacterial infection of the respiratory tract, (3) discharge at request. The first 2 patients received an individual rehabilitation program. Baseline characteristics of both groups are shown in Table I.

\section{Treadmill exercise stress tests}

There were no differences between groups at baseline, except for HR recovery in 1 minute that was faster in the control group $(p=0.002)$. After interventions significant changes in METs, $\mathrm{VO}_{2}$, duration, peak $\mathrm{HR}$, percentage of peak $H R$ in relation to $H R_{\text {max }}, H R$ reserve, and $H R$ recovery at 3 and 4 minutes were observed in both groups. Statistically significant improvements after intervention in systolic blood pressure (SBP), HR and DP at peak exercise load in the baseline test, resting HR, HR recovery in 1 minute and resting DP (on the borderline of significance) were seen only in the study group (Table II). No statistically significant differences were found between groups in the final test.

\section{Six-minute walk tests}

No differences were found between groups at baseline and after rehabilitation. A significant increase in walking distance, mean walking speed, percentage of predicted walking distance and $\mathrm{HR}$ reserve were observed in both cohorts (Table III). Mean increment of walking distance was 99 (55) m ( $p<0.001)$, which was 27\% (26) ( $p<0.001)$ of baseline distance in the study group. These values were lower in the control group at $72(43) \mathrm{m}(p<0.001)$ and $17 \%$ (11) $(p<0.001)$, respectively. Significant reduction in resting $\mathrm{HR}$ and DP after intervention was noted only in the study group. Energy expenditure and $\mathrm{VO}_{2}$ increased in the final test in both cohorts.

\section{Training programs}

Statistical analysis showed homogeneity of both groups in terms of mean values of all studied parameters (Table IV).

We noted a statistically significant gradual increase in mean duration of training from session 3 (16.1 (4.5) minutes, $p<0.05)$, mean treadmill walking speed from session 7 (3.1 (0.6) km/h, $p<0.05)$, mean energy expenditure
Table I. Baseline characteristics

\begin{tabular}{|c|c|c|c|}
\hline Variable & $\begin{array}{c}\text { Study } \\
\text { group } \\
(n=20)\end{array}$ & $\begin{array}{l}\text { Control } \\
\text { group } \\
(n=21)\end{array}$ & $P$-value \\
\hline \multicolumn{4}{|l|}{ Demographics, mean (SD): } \\
\hline Age [years] & $63(6)$ & $61(7)$ & NS \\
\hline $\mathrm{BMI}\left[\mathrm{kg} / \mathrm{m}^{2}\right]$ & $28.7(4.3)$ & $29.9(5.1)$ & NS \\
\hline Waist circumference $[\mathrm{cm}]$ & $103(12)$ & $103(12)$ & NS \\
\hline Prior surgical revascularization, $n(\%)$ & $5(25)$ & $6(29)$ & NS \\
\hline \multicolumn{4}{|l|}{ Comorbidities, $n$ (\%): } \\
\hline Chronic ischemic heart disease & $20(100)$ & $21(100)$ & NS \\
\hline Hypertension & $18(90)$ & $19(90)$ & NS \\
\hline Type 2 diabetes & $4(20)$ & $7(33)$ & NS \\
\hline $\begin{array}{l}\text { Other carbohydrate metabolism } \\
\text { disorders }\end{array}$ & $4(20)$ & $3(14)$ & NS \\
\hline Lipid metabolism disorders & $14(70)$ & $18(86)$ & NS \\
\hline Prior myocardial infarction & $8(40)$ & $17(81)$ & 0.007 \\
\hline \multicolumn{4}{|l|}{ Surgical technique: } \\
\hline CABG & $15(75)$ & $15(71)$ & NS \\
\hline OPCAB & $4(20)$ & $6(29)$ & NS \\
\hline MIDCAB & $1(5)$ & - & NS \\
\hline \multicolumn{4}{|l|}{ Number of grafts, $n(\%)$ : } \\
\hline 1 & $3(15)$ & $1(5)$ & NS \\
\hline 2 & $2(10)$ & $7(33)$ & NS \\
\hline 3 & $13(65)$ & $10(48)$ & NS \\
\hline 4 & $2(10)$ & $3(14)$ & NS \\
\hline \multicolumn{4}{|l|}{ Postoperative medication, $n(\%)$ : } \\
\hline Statins & $20(100)$ & $21(100)$ & NS \\
\hline Beta-blockers & $20(100)$ & $21(100)$ & NS \\
\hline Aspirin & $20(100)$ & $21(100)$ & NS \\
\hline Sulfonamides & $18(90)$ & $18(86)$ & NS \\
\hline Potassium & $17(85)$ & $15(71)$ & NS \\
\hline PPIs & $14(70)$ & $16(76)$ & NS \\
\hline ACE inhibitors & $13(65)$ & $12(57)$ & NS \\
\hline Aldosterone antagonists & $12(60)$ & $6(29)$ & 0.04 \\
\hline Ivabradine & $4(20)$ & $4(19)$ & NS \\
\hline ARBs & $3(15)$ & $3(14)$ & NS \\
\hline CCBs & $2(10)$ & $5(24)$ & NS \\
\hline LVEF, \%, mean (SD) & $52(7)$ & $52(7)$ & NS \\
\hline Pericardial effusion, $n(\%)$ & $7(35)$ & $7(33)$ & NS \\
\hline
\end{tabular}

ACE - angiotensin-converting enzyme, ARBs - angiotensin II receptor blockers, $\mathrm{BMI}$ - body mass index, CABG - coronary artery bypass grafting, CCBs - calcium channel blockers, LVEF - left ventricular ejection fraction, MIDCAB - minimally invasive direct coronary artery bypass, OPCAB - off-pump coronary artery bypass, PPIs - proton pump inhibitors.

from session 7 (2.6 (0.3) MET, $p<0.05)$, and mean caloric expenditure from session 5 (66 (21) kcal, $p<0.05)$ in the study group. In the control group we observed a significant increase in mean energy and caloric expenditure from session 6 that amounted to $2.8(0.3)$ MET $(p<0.05)$ and 66 (15) kcal $(p<0.05)$, respectively. 
Two early rehabilitation training models in male patients after coronary artery bypass surgery: application of continuous walking training as an alternative to interval cycle ergometer training

Table II. Comparison of baseline and post-intervention outcomes of treadmill exercise stress tests in both groups

\begin{tabular}{|c|c|c|c|c|c|c|}
\hline \multirow[t]{2}{*}{ Variable } & \multicolumn{3}{|c|}{ Study group $(n=20)$} & \multicolumn{3}{|c|}{ Control group $(n=21)$} \\
\hline & Baseline & $\begin{array}{c}\text { After } \\
\text { intervention }\end{array}$ & $P$-value & Baseline & $\begin{array}{c}\text { After } \\
\text { intervention }\end{array}$ & $P$-value \\
\hline METs & $4.4(1.4)$ & $6.3(1.3)$ & $<0.001$ & $5.0(1.4)$ & $6.5(1.4)$ & $<0.001$ \\
\hline Oxygen uptake $[\mathrm{ml} / \mathrm{kg} / \mathrm{min}]$ & $15.4(4.9)$ & $22.1(4.6)$ & $<0.001$ & $17.5(4.9)$ & $22.8(4.9)$ & $<0.001$ \\
\hline Duration [min] & $6(2)$ & $8(2)$ & $<0.001$ & $7(2)$ & $8(2)$ & $<0.001$ \\
\hline RPE & $14(1)$ & $14(1)$ & NS & $15(1)$ & $15(1)$ & NS \\
\hline Rest SBP $[\mathrm{mm} \mathrm{Hg}]$ & $113(14)$ & $113(12)$ & NS & $111(13)$ & $111(14)$ & NS \\
\hline $\begin{array}{l}\text { SBP at peak exercise load in baseline } \\
\text { test }[\mathrm{mm} \mathrm{Hg}]\end{array}$ & $162(21)$ & $145(24)$ & $<0.001$ & $153(14)$ & $153(19)$ & NS \\
\hline Peak SBP [mm Hg] & $162(21)$ & $163(25)$ & NS & $153(14)$ & $164(21)$ & 0.005 \\
\hline Rest DBP $[\mathrm{mm} \mathrm{Hg}]$ & $71(8)$ & $70(7)$ & NS & $68(8)$ & $68(8)$ & NS \\
\hline Peak DBP [mm Hg] & $87(6)$ & $86(9)$ & NS & $84(5)$ & $87(7)$ & 0.03 \\
\hline Rest HR [mm Hg] & $86(6)$ & $79(9)$ & 0.004 & $82(14)$ & 77 (14) & NS \\
\hline Peak HR [mm Hg] & $113(11)$ & $120(14)$ & 0.03 & $113(17)$ & $118(18)$ & 0.005 \\
\hline $\begin{array}{l}\text { HR at peak exercise load in baseline } \\
\text { test [bpm] }\end{array}$ & $113(11)$ & $104(15)$ & $<0.001$ & $113(17)$ & $109(21)$ & NS \\
\hline Peak $\mathrm{HR}-\%$ of $\mathrm{HR}_{\max }$ & $73(8)$ & $76(9)$ & 0.04 & $72(12)$ & $75(13)$ & 0.01 \\
\hline HR reserve [bpm] & $28(10)$ & $41(10)$ & $<0.001$ & $31(15)$ & $41(13)$ & $<0.001$ \\
\hline HR recovery at $1 \mathrm{~min}[\mathrm{bpm}]$ & $7(4)$ & $17(14)$ & $<0.001$ & $12(5)$ & $14(6)$ & NS \\
\hline HR recovery at $3 \mathrm{~min}[\mathrm{bpm}]$ & $29(8)$ & $40(14)$ & $<0.001$ & $32(12)$ & $37(10)$ & 0.003 \\
\hline HR recovery at $4 \min [\mathrm{bpm}]$ & $29(7)$ & $40(14)$ & $<0.001$ & $32(12)$ & $39(12)$ & $<0.001$ \\
\hline Rest DP & $9710(1215)$ & $8972(1315)$ & NS (0.0505) & $9095(1606)$ & $8559(1769)$ & NS \\
\hline Peak DP & 18469 (3 619) & $19620(4042)$ & NS & $17223(2827)$ & 19418 (3 800) & 0.001 \\
\hline DP at peak exercise load in baseline test & 18469 (3 619) & $15151(4364)$ & $<0.001$ & $17223(2827)$ & 16746 (3 858) & NS \\
\hline
\end{tabular}

Table III. Comparison of baseline and after intervention outcomes of six-minute walk tests in both groups

\begin{tabular}{|c|c|c|c|c|c|c|}
\hline \multirow[t]{2}{*}{ Variable } & \multicolumn{3}{|c|}{ Study group $(n=20)$} & \multicolumn{3}{|c|}{ Control group $(n=21)$} \\
\hline & Baseline & After intervention & $P$-value & Baseline & After intervention & $P$-value \\
\hline Distance $[\mathrm{m}]$ & $420(80)$ & $519(61)$ & $<0.001$ & $438(58)$ & $510(63)$ & $<0.001$ \\
\hline Speed $[\mathrm{km} / \mathrm{h}]$ & $4.2(0.8)$ & $5.2(0.6)$ & $<0.001$ & $4.4(0.6)$ & $5.1(0.6)$ & $<0.001$ \\
\hline Distance $-\%$ predicted & $70(14)$ & $86(11)$ & $<0.001$ & $73(11)$ & $84(12)$ & $<0.001$ \\
\hline METs & $3.3(0.6)$ & $3.8(0.5)$ & $<0.001$ & $3.4(0.6)$ & $3.9(0.7)$ & $<0.001$ \\
\hline Oxygen uptake $[\mathrm{ml} / \mathrm{kg} / \mathrm{min}]$ & $11.4(2.3)$ & $13.5(1.9)$ & $<0.001$ & $11.7(2.2)$ & $13.5(2.4)$ & $<0.001$ \\
\hline RPE & $12(2)$ & $11(2)$ & NS & $12(2)$ & $12(2)$ & NS \\
\hline Rest SBP $[\mathrm{mm} \mathrm{Hg}]$ & $115(16)$ & $113(14)$ & NS & $112(10)$ & $115(10)$ & NS \\
\hline Peak SBP [mm Hg] & $128(17)$ & $129(16)$ & NS & $125(11)$ & $133(12)$ & 0.007 \\
\hline Rest DBP [mm Hg] & $66(9)$ & $64(8)$ & NS & $62(7)$ & $62(8)$ & NS \\
\hline Peak DBP [mm Hg] & $69(9)$ & $68(7)$ & NS & $65(8)$ & $67(9)$ & NS \\
\hline Rest HR [bpm] & $76(10)$ & $72(8)$ & 0.03 & $73(10)$ & $72(11)$ & NS \\
\hline Peak HR [bpm] & $96(10)$ & $97(10)$ & NS & $93(13)$ & 97 (14) & NS \\
\hline Peak $\mathrm{HR}-\%$ of $\mathrm{HR}_{\max }$ & $64(7)$ & $64(7)$ & NS & $61(9)$ & $64(10)$ & NS \\
\hline HR reserve [bpm] & $20(8)$ & $25(7)$ & 0.03 & $19(8)$ & $25(10)$ & 0.003 \\
\hline Rest DP & 8711 (1 151) & $8160\left(\begin{array}{lll}1 & 123\end{array}\right)$ & 0.03 & $8201(1244)$ & 8289 (1 684) & NS \\
\hline Peak DP & 12295 (1 877) & 12533 (2 154) & NS & 11625 (2 080) & 12923 (2 544) & NS \\
\hline
\end{tabular}

Data are presented as mean (SD). DBP - diastolic blood pressure, DP - double product, HR - heart rate, MET - metabolic equivalent, RPE - rating of perceived exertion, SBP - systolic blood pressure. 
There were no differences between groups referring to $B L C$ at rest and after exertion either in session 6 or 12. BLC did not increase significantly after exertion (Table V).

No serious arrhythmias were noted during training sessions and no other adverse events were reported while exercising in either group.

\section{Discussion}

This study presents a model of low intensity walking training as an alternative to the commonly used cycle ergometer training in men after CABG surgery. According to the literature peak $\mathrm{VO}_{2}$ is a strong predictor of mortality in patients with coronary artery disease. A study by Kavanagh et al. [14] showed that values of 15 to $22 \mathrm{ml} / \mathrm{kg} / \mathrm{min}(4.3$ to 6.3 METs) and above $22 \mathrm{ml} / \mathrm{kg} / \mathrm{min}$ (6.3 METs) yielded, respectively, a $38 \%$ and $61 \%$ reduction in risk of cardiac death over the follow-up period. We speculate that an average $35 \%$ increase in $\mathrm{VO}_{2}$ may indicate a reduction in risk of death in examined patients. This outcome falls within the range of results $(10.5 \%$ to $48.2 \%$, corresponding to 1.9 to $6.6 \mathrm{ml} / \mathrm{kg} / \mathrm{min}$ ) obtained in 17 other studies involving patients after CABG surgery [15].

Various factors may have affected the final outcome of cardiac rehabilitation, such as age, body mass index (BMI), comorbidities, initial level of physical capacity, commencement and duration of the rehabilitation program, type of exercise training, prescribed medications and low level of physical activity prior rehabilitation [16-19]. It should be noted that most of our patients had previous myocardial infarction (MI), and MET values underestimate the exercise intensity in post-MI men during the modified Bruce treadmill walking test. Patients exceed the anaerobic threshold faster with a lower rating of perceived exertion [20].

The reduction in SBP at peak exercise load in the baseline test that we observed in the final TEST may indicate a better BP response to exertion in the study group. The proposed form of walking training probably increased the efficiency of myocardial work by the heart muscle performing less work at the same load on the body with physical effort [21]. More frequent intake of aldosterone antagonists in the study group probably did not affect peak BP in control tests. The study conducted by Kosmala et al. [22] confirmed only a reducing effect of the drug on resting BP.

In final tests we observed a decrease in resting $\mathrm{HR}$ and $\mathrm{HR}$ at peak exercise load in the baseline test only in the study group. This may indicate a beneficial effect of walking training on improvement of exercise tolerance caused by post-exercise reactivation of vagus nerve tension [23-25].
Table IV. Mean values of studied training parameters

\begin{tabular}{lccc} 
Variable & $\begin{array}{c}\text { Study group } \\
(n=20)\end{array}$ & $\begin{array}{c}\text { Control group } \\
(n=21)\end{array}$ & P-value \\
Duration [min] & $17(2)$ & $17(2)$ & NS \\
\hline Rest SBP [mm Hg] & $115(11)$ & $116(10)$ & NS \\
\hline Peak SBP [mm Hg] & $122(12)$ & $123(11)$ & NS \\
\hline Rest DBP [mm Hg] & $65(6)$ & $66(4)$ & NS \\
\hline Peak DBP [mm Hg] & $68(7)$ & $70(5)$ & NS \\
\hline Rest HR [bpm] & $77(7)$ & $75(8)$ & NS \\
\hline Peak HR [bpm] & $91(8)$ & $88(11)$ & NS \\
\hline Rest DP & $8874(1074)$ & $8634(972)$ & NS \\
\hline Peak DP & $11163(1673)$ & $10805(1428)$ & NS \\
\hline RPE & $10(2)$ & $10(1)$ & NS \\
\hline Energy expenditure [MET] & $2.6(0.3)$ & $2.8(0.3)$ & NS \\
\hline Caloric expenditure [kcal] & $68(17)$ & $66(14)$ & NS \\
\hline
\end{tabular}

Data are presented as mean (SD). DBP - diastolic blood pressure, DP - double product, $\mathrm{HR}$ - heart rate, $M E T$ - metabolic equivalent, $R P E$ - rating of perceived exertion, SBP - systolic blood pressure.

In addition, the lack of significant decrease in resting HR in the control group may result from the significantly more frequent occurrence of previous myocardial infarction in this group ( $40 \%$ vs. $81 \%$ ). As a consequence of myocardial infarction, the sympathetic-parasympathetic balance becomes impaired, which may be manifested by elevated resting HR that reflects greater neurohormonal activation [26]. It should be borne in mind, however, that mean LVEF was the same in both groups at $52 \%$.

The increase in peak $H R$ and percentage of $H R_{\text {max }}$ that we found in both groups in final tests indicates a normal response of the cardiovascular and the nervous systems to physical effort [25]. We also observed an increase in HR reserve, which can be an indicator of progression of physical exercise load on the cardiovascular system [27].

In the final TEST, HR reserve increased from $40 \%$ (15) to $54 \%(17)(p<0.001)$ in the study group, and from $41 \%(23)$ to $53 \%(22)(p<0.001)$ in the control group. We defined impaired HR reserve as below $62 \%$ because all patients were treated with $\beta$-blockers $[28,29]$. Our data suggest that this chronotropic incompetence may be associated with an increased risk of major adverse cardiac events [28], but it can be assumed that continuation of regular physical activity will contribute to a further increase in HR reserve. An imbalance between sympathetic and parasympathetic components of the autonomic nervous system may limit HR reserve during exercise [26]. Other studies suggest that

Table V. Blood lactate concentrations ( $\mathrm{mmol} / \mathrm{l}$ ) during training

\begin{tabular}{lcccccc} 
Session & \multicolumn{3}{c}{ Study group $(n=20)$} & \multicolumn{3}{c}{ Control group $(n=21)$} \\
\cline { 2 - 7 } & At rest & After exertion & P-value & At rest & After exertion & P-value \\
\hline 12 & $1.7(0.6)$ & $2.0(0.9)$ & NS & $1.9(0.6)$ & $2.0(0.5)$ & NS \\
\hline
\end{tabular}

Data are presented as mean (SD). 
Two early rehabilitation training models in male patients after coronary artery bypass surgery: application of continuous walking training as an alternative to interval cycle ergometer training

an impaired HR reserve protects the myocardium from high $\mathrm{HR}$ values and associated demand for coronary blood flow [30].

Studies indicate a strong relationship between slower $H R$ recovery and insufficient perfusion of the myocardium [31-34]. In the final TEST we observed faster HR recovery in 3 and 4 minutes in both groups and in 1 minute only in the study group. Final outcomes may indicate similar therapeutic effectiveness of both types of training that was manifested by acceleration of HR recovery in 1 minute to values above $12 \mathrm{bpm}$, which are normal [21,35]. This could be due to increased activity of the parasympathetic nervous system following physical activity [21]. Similar results were obtained by authors of other studies [36-38].

According to the literature, DP is a good indicator of myocardial workload and is often used in clinical practice $[39,40]$, but $\beta$-blocker intake may significantly reduce its value [41]. Our final results indicate a myocardial oxygen demand reduction at rest in the study group [39, 42, 43]. Exercise DP remained at a similar level in both groups, therefore myocardial workload and demand for oxygen were similar, as in the Moradi et al. [40] research. Exercise DP at peak exercise load in the baseline test decreased only in the study group. Probably, as a result of applied walking training, we observed an improvement in physical exercise tolerance expressed in decrease in myocardial oxygen demand during constant load [39-43].

We noted an increase in walking distance by 99 (55) $\mathrm{m}$ (27\% (26)) in the study group and by 72 (43) m (17\% (11)) in the control group. According to Fiorina et al. [44], an increase in walking distance above $10 \%$ indicates a significant improvement in the patient's exercise tolerance and functional status. Walking distance of $300 \mathrm{~m}$ [45-47] or $350 \mathrm{~m}$ [48] is the value above which the patient's prognosis becomes good, and therefore average results of our participants should be considered clinically beneficial.

We did not observe changes in HR, BP and DP during training sessions, probably due to too short duration of rehabilitation programs. Average rating of perceived exertion during training was 10 and it corresponds to low-intensity training below 3 METs and $20 \%$ to $40 \%$ of HR reserve. This degree of intensity is particularly important at an early stage of rehabilitation after CABG surgery, because most basic activities of everyday life are carried out at this level of intensity [49].

All patients also participated twice a day in full-body exercises during which they spent about $60 \mathrm{kcal}$ per session [50]. It resulted in an average expenditure of approximately $190 \mathrm{kcal} /$ day during supervised activities, which is consistent with recommendations [51].

Measurement of BLC allows optimization of the effectiveness of rehabilitation programs, determining their structure and maximizing health benefits while minimizing the risk of adverse events [52]. Mean resting BLC in both groups was within the normal range $(0.6-2.0 \mathrm{mmol} / \mathrm{l})$ developed by the laboratory where analyses were carried out. Resting BLC remained unchanged regardless of physical training. Mean levels of lactate after exercise $\leq 2.0 \mathrm{mmol} / \mathrm{l}$ indicated the aerobic form of proposed training [3]. We noted that BLC after the $6^{\text {th }}$ and $12^{\text {th }}$ training session remained at a similar level despite an increase in their intensity. This may suggest an improvement in physical exercise tolerance expressed by more efficient utilization of lactate [53].

Although our results have application value for cardiac rehabilitation, our study also has limitations. First, the sample size was small $(n=41)$, due to occurrence of exclusion criteria in a significant number of patients. Second, we did not include women in our study, because men undergo CABG surgery 4-5 times more often than women [54]. Participation of women in a small sample could significantly affect the results of our study.

\section{Conclusions}

The proposed model of low intensity walking training is of similar effectiveness to cycle ergometer training in improving exercise tolerance in men at an early stage of rehabilitation after coronary artery bypass surgery and can be used alternatively. The initial training load in walking training in men after coronary artery bypass surgery can be determined based on a 6-minute walk test. Intensity of both training programs in men at an early stage of rehabilitation after coronary artery bypass surgery does not lead to exceeding the anaerobic threshold.

\section{Disclosure}

Authors report no conflict of interest.

\section{References}

1. Timmis A, Townsend N, Gale CP, et al. European Society of Cardiology: Cardiovascular Disease Statistics 2019. Eur Heart J 2020; 41: 12-85.

2. Doyle MP, Indraratna P, Tardo DT, et al. Safety and efficacy of aerobic exercise commenced early after cardiac surgery: a systematic review and metaanalysis. Eur J Prev Cardiol 2019; 26: 36-45.

3. Smarż K, Jaxa-Chamiec T, Chwyczko T, et al. Cardiopulmonary exercise testing in adult cardiology: expert opinion of the Working Group of Cardiac Rehabilitation and Exercise Physiology of the Polish Cardiac Society. Kardiol Pol 2019; 77: 730-756.

4. Sobczak D, Dylewicz P. The application of walking training in the rehabilitation of patients after coronary artery bypass grafting. Kardiochir Torakochir Pol 2015; 12: 275-287.

5. Fletcher GF, Ades PA, Kligfield P, et al. Exercise standards for testing and training: a scientific statement from the American Heart Association. Circulation 2013; 128: 873-934.

6. Ainsworth BE, Haskell WL, Herrmann SD, et al. 2011 Compendium of Physical Activities: a second update of codes and MET values. Med Sci Sports Exerc 2011; 43: 1575-1581.

7. ATS Committee on Proficiency Standards for Clinical Pulmonary Function Laboratories. ATS statement: guidelines for the six-minute walk test. Am J Respir Crit Care Med 2002; 166: 111-117.

8. Duncan MJ, Mota J, Carvalho J, Nevill AM. An evaluation of prediction equations for the 6 minute walk test in healthy European adults aged $50-85$ years. PLoS One 2015; 10: e0139629.

9. Duncan MJ, Mota J, Carvalho J, Nevill AM. Correction: an evaluation of prediction equations for the 6 minute walk test in healthy European adults aged 50-85 years. PLoS One 2015; 10: e0142463.

10. Cahalin LP, Mathier MA, Semigran MJ, et al. The six-minute walk test predicts peak oxygen uptake and survival in patients with advanced heart failure. Chest 1996; 110: 325-332. 
11. American Association of Cardiovascular and Pulmonary Rehabilitation. Guidelines for Cardiac Rehabilitation and Secondary Prevention Programs. $5^{\text {th }}$ ed. Champaign, IL: Human Kinetics 2013.

12. American College of Sports Medicine. ACSM's Guidelines for Exercise Testing and Prescription. 10 $0^{\text {th }}$ ed. Lippincott Williams \& Wilkins, Philadelphia, PA 2018.

13. Maughan RJ. A simple, rapid method for the determination of glucose, lactate, pyruvate, alanine, 3-hydroxybutyrate and acetoacetate on a single 20mul blood sample. Clin Chim Acta 1982; 122: 231-240.

14. Kavanagh T, Mertens DJ, Hamm LF, et al. Prediction of long-term prognosis in 12169 men referred for cardiac rehabilitation. Circulation 2002; 106: 666-671.

15. Lan C, Chen SY, Lai JS. Exercise training for patients after coronary artery bypass grafting surgery. In: Acute Coronary Syndromes. Brizzio M (ed.). IntechOpen 2012; 117-128.

16. Price KJ, Gordon BA, Bird SR, et al. A review of guidelines for cardiac rehabilitation exercise programmes: Is there an international consensus? Eur J Prev Cardiol 2016; 23: 1715-1733.

17. Minotto M, Harrison AS, Grazzi G, et al. What factors are associated with patients walking fitness when starting cardiac rehabilitation? Int J Cardiol Heart Vasc 2018; 22: 26-30.

18. Niebauer J. Is there a role for cardiac rehabilitation after coronary artery bypass grafting? Treatment after coronary artery bypass surgery remains incomplete without rehabilitation. Circulation 2016; 133: 2529-2537.

19. Mendes $\mathrm{M}$. Is there a role for cardiac rehabilitation after coronary artery bypass grafting? There is no role for cardiac rehabilitation after coronary artery bypass grafting. Circulation 2016; 133: 2538-2543.

20. Woolf-May K, Meadows S, Ferrett D, et al. Metabolic equivalents fail to indicate metabolic load in post-myocardial infarction patients during the modified Bruce treadmill walking test. BMJ Open Sport Exerc Med 2017; 2: e000173.

21. Balsam P, Szmit S. Aktywność fizyczna a ciśnienie tętnicze krwi. Kardiol Dypl 2011; 10: 68-72.

22. Kosmala W, Rojek A, Przewlocka-Kosmala M, et al. Effect of aldosterone antagonism on exercise tolerance in heart failure with preserved ejection fraction. J Am Coll Cardiol 2016; 68: 1823-1834.

23. Carter JB, Banister EW, Blaber AP. Effect of endurance exercise on autonomic control of heart rate. Sports Med 2003; 33: 33-46.

24. Lucini D, Milani RV, Costantino G, et al. Effects of cardiac rehabilitation and exercise training on autonomic regulation in patients with coronary artery disease. Am Heart J 2002; 143: 977-983.

25. Tsai SW, Lin YW, Wu SK. The effect of cardiac rehabilitation on recovery of heart rate over one minute after exercise in patients with coronary artery bypass graft surgery. Clin Rehabil 2005; 19: 843-849.

26. Besnier F, Labrunée $M$, Pathak $A$, et al. Exercise training-induced modification in autonomic nervous system: an update for cardiac patients. Ann Phys Rehabil Med 2017; 60: 27-35.

27. Grace $F$, Herbert $P$, Elliott $A D$, et al. High intensity interval training (HIIT) improves resting blood pressure, metabolic (MET) capacity and heart rate reserve without compromising cardiac function in sedentary aging men. Exp Gerontol 2018; 109: 75-81.

28. Hong SP, Lee YS, Lee JB, et al. Prognostic value of heart rate reserve in exercise treadmill test after coronary revascularization. Intern Med 2014; 4: 175.

29. Khan MN, Pothier CE, Lauer MS. Chronotropic incompetence as a predictor of death among patients with normal electrograms taking beta blockers (metoprolol or atenolol). Am J Cardiol 2005; 96: 1328-1333.

30. Rosenwinkel ET, Bloomfield DM, Arwady MA, Goldsmith RL. Exercise and autonomic function in health and cardiovascular disease. Cardiol Clin 2001; 19: 369-387.

31. Ghaffari S, Kazemi B, Aliakbarzadeh P. Abnormal heart rate recovery after exercise predicts coronary artery disease severity. Cardiol J 2011; 18: 47-54.

32. Georgoulias P, Orfanakis A, Demakopoulos N, et al. Abnormal heart rate recovery immediately after treadmill testing: correlation with clinical, exercise testing, and myocardial perfusion parameters. J Nucl Cardiol 2003; 10: 498-505.
33. Lima RS, De Lorenzo A, Soares AJ. Relation between postexercise abnorma heart rate recovery and myocardial damage evidenced by gated single-photon emission computed tomography. Am J Cardiol 2006; 97: 1452-1454.

34. Morshedi-Meibodi A, Larson MG, Levy D, et al. Heart rate recovery after treadmill exercise testing and risk of cardiovascular disease events (The Framingham Heart Study). Am J Cardiol 2002; 90: 848-852.

35. Jolly MA, Brennan DM, Cho L. Impact of exercise on heart rate recovery. Circulation 2011; 124: 1520-1526.

36. Racine N, Blanchet $M$, Ducharme A, et al. Decreased heart rate recovery after exercise in patients with congestive heart failure: effect of beta-blocker therapy. J Card Fail 2003; 9: 296-302.

37. Spiroski D, Andjić M, Stojanović Ol, et al. Very short/short-term benefit of inpatient/outpatient cardiac rehabilitation programs after coronary artery bypass grafting surgery. Clin Cardiol 2017; 40: 281-286.

38. Tiukinhoy S, Beohar N, Hsie M. Improvement in heart rate recovery after cardiac rehabilitation. J Cardiopulm Rehabil 2003; 23: 84-87.

39. Jasik M. Podwójny iloczyn: znany parametr w nowej roli? Kardiol Pol 2013 71: 53-54.

40. Moradi M, Fariba F. A comparative study of the double product index before and after cardiac rehabilitation in patients undergoing coronary artery bypass grafting. Ann Trop Med Public Health 2017; 10: 950-955.

41. Izzo JL Jr, Khan SU, Saleem O, Osmond PJ. Ambulatory 24-hour cardiac oxygen consumption and blood pressure-heart rate variability: effects of nebivolol and valsartan alone and in combination. J Am Soc Hypertens 2015; 9: 526-535

42. Zielińska D, Rynkiewicz A, Zajt-Kwiatkowska J, et al. Wpływ kompleksowe rehabilitacji kardiologicznej na wydolność fizyczną i jakość życia chorych z upośledzoną czynnością lewej komory. Folia Cardiol Exc 2006; 13: 208-217.

43. Szmit S, Filipiak KJ. Czy u pacjenta z chorobą serca ważna jest aktywność fizyczna? Przew Lek 2007; 10: 32-38.

44. Fiorina C, Vizzardi E, Lorusso R, et al. The 6-min walking test early after cardiac surgery. Reference values and the effects of rehabilitation programme. Eur J Cardiothorac Surg 2007; 32: 724-729.

45. Rostagno C, Olivo G, Comeglio M, et al. Prognostic value of 6-minute walk corridor test in patients with mild to moderate heart failure: comparison with other methods of functional evaluation. Eur J Heart Fail 2003; 5: 247-252.

46. Manzano L, Babalis D, Roughton M, et al. Predictors of clinical outcomes in elderly patients with heart failure. Eur J Heart Fail 2011; 13: 528-536.

47. Cacciatore F, Abete P, Mazzella F, et al. Six-minute walking test but not ejection fraction predicts mortality in elderly patients undergoing cardiac rehabilitation following coronary artery bypass grafting. Eur J Prev Cardiol 2012 19: 1401-1409.

48. Baptista VC, Palhares LC, de Oliveira PP, et al. Six-minute walk test as a tool for assessing the quality of life in patients undergoing coronary artery bypass grafting surgery. Rev Bras Cir Cardiovasc 2012; 27: 231-239.

49. Norton K, Norton L, Sadgrove D. Position statement on physical activity and exercise intensity terminology. J Sci Med Sport 2010; 13: 496-502.

50. Bushman BA. How can I use METS to quantify the amount of aerobic exercise. ACSMs Health Fit J 2012; 16: 5-7.

51. Balady GJ, Williams MA, Ades PA, et al. Core components of cardiac rehabilitation/secondary prevention programs: 2007 update: a scientific statement from the American Heart Association Exercise, Cardiac Rehabilitation, and Prevention Committee, the Council on Clinical Cardiology, the Councils on Cardiovascular Nursing, Epidemiology and Prevention, and Nutrition, Physical Activity, and Metabolism, and the American Association of Cardiovascular and Pulmonary Rehabilitation. Circulation 2007; 115: 2675-2682.

52. Heitkamp HC, Hipp A. Lactate in cardiac rehabilitation. Herz 2001; 26: 447453.

53. Bogdanis GC. Effects of physical activity and inactivity on muscle fatigue. Front Physiol 2012; 3: 142.

54. Nielsen S, Björck L, Jeppsson A, et al. Trends in mortality risks among 94,328 patients surviving 30days after a first isolated coronary artery bypass graft procedure from 1987 to 2006: a population-based study. Int J Cardiol 2017; 244: $316-321$ 